\title{
Retraction of Study of the Effect of Environmental Education on Environmental Awareness and Environmental Attitude Based on Environmental Protection Law of the People's Republic of China
}

\author{
Yang Li *
}

Issue Date: 22 December 2018

Original Article: Study of the Effect of Environmental Education on Environmental Awareness and Environmental Attitude Based on Environmental Protection Law of the People's Republic of China EURASIA J. Math., Sci Tech. Ed (2018), 14(6), 2277-2285.

https://doi.org/10.29333/ejmste/86214

This document states that the Article is retracted by request from the author.

http://www.ejmste.com

(C) 2019 by the authors; licensee Modestum Ltd., UK. This article is an open access article distributed under the terms and conditions of the Creative Commons Attribution License (http://creativecommons.org/licenses/by/4.0/). 《13552073677@139.com (Correspondence) 